\title{
Pemasangan Lampu Jalan Tenaga Surya Di Kampung Benda Desa Mekarjaya, Panongan - Tangerang
}

\author{
Taryana $^{1}$, Yayuk Suprihartini ${ }^{2}$, Rubby Soebiantoro $^{3}$, Asep Samanhudi ${ }^{4}$ \\ 1,2,3,4Politeknik Penerbangan Indonesia Curug \\ e-mail: 1taryana@ppicurug.ac.id, ${ }^{2}$ yayuk.suprihartini@ppicurug.ac.id, \\ 33ubby.soebiantoro@ppicurug.ac.id, ${ }^{4}$ asep_samanhudi@ppicurug.ac.id
}

\begin{abstract}
Abstrak
Jalan adalah akses penting bagi warga untuk beraktifitas, tetapi jika jalan tidak dilengkapi dengan penerangan maka hal tersebut akan menjadi kendala, terutama pada malam hari. Lampu penerangan jalan adalah sesuatu hal yang sangat dibutuhkan oleh warga khususnya di daerah pedesaan. Penerangan jalan merupakan sarana yang sangat dibutuhkan oleh warga di Kp. Blok Benda RT.10 RW. 04 Desa Mekar Jaya Kec. Panongan Tangerang Banten.Oleh sebab itu, masyarakat Kp.Blok Benda Mekar Jaya menginginkan pengadaan serta pemasangan penerangan lampu jalan segera dilaksanakan di sepanjang jalan yangtermasuk pada wilayah Panongan, khususnya jalan yang dianggap rawan perbuatan tindak criminal/pembegalan. Melihat adanya permintaan warga yang sangat membutuhkan penerangan jalan ini, maka kami melaksanakan Tri Darma Perguruan Tinggi dimana Politeknik Penerbangan Indonesia Curug salah satu kewajiban dosen dalam melaksanakan pengabdian pada masyarakat dengan mengambil kasus
\end{abstract}

Kata Kunci : Pengabdian, Penerangan, Solarcell

Abstract

The road is an important access for residents to do activities, but if the road is not equipped with lighting it will become an obstacle, especially at night. Street lighting is something that is really needed by residents, especially in rural areas. Street lighting is a tool that is needed by residents in Kp. Blok Benda RT.10 RW. 04 Desa Mekar Jaya Kec. Panongan Tangerang Banten. Therefore, the people of Kp. Blok Benda Mekar Jaya want the procurement and installation of street lighting to be carried out immediately along the roads belonging to the Panongan area, especially roads that are considered prone to criminal acts / theft Seeing the demand for residents who really need street lighting, we implemented the Tri Darma Perguruan Tinggi where the Indonesian Aviation Polytechnic Curug is one of the lecturers' obligations in carrying out community service by taking cases

Keywords : Dedication, Lighting, Solarcell

\section{Pendahuluan}

\section{Analisis Situasi}

Jalan adalah akses penting bagi warga untuk beraktifitas, tetapi jika jalan tidak dilengkapi dengan penerangan maka hal tersebut akan menjadi kendala, terutama pada malam hari. Lampu penerangan jalan adalah sesuatu hal yang sangat dibutuhkan oleh warga khususnya di daerah pedesaan. Penerangan jalan merupakan sarana yang sangat dibutuhkan oleh warga di Kp. Blok Benda RT.10 RW. 04 Desa Mekar Jaya Kec. Panongan Tangerang Banten

Berdasarkan permintaan dari warga setempat, penerangan jalan ini sangat dibutuhkan. Akan tetapi, pemasangan lampu jalan di Kp.Blok Benda Mekar Jaya perlu adanya ijin dari kelurahan dan kecamatan serta biaya yang diperlukan untuk membuat penerangan jalan. Penerangan jalan memiliki manfaat yang sangat besar bagi seluruh masyarakat khususnya di kawasan pedesaan. Banyak wilayah di daerah pedesaan yang sangat bantuan untuk 
pemasangan penerangan jalan. Dalam hal ini kami mengajukan permohonan bantuan untuk pengadaan penerangan jalan di Kp. Blok Benda RT.10 RW. 04 Desa Mekar Jaya Kec. Panongan Tangerang Banten

Masyarakat Kp.Blok Benda Mekar Jaya menginginkan pengadaan serta pemasangan penerangan lampu jalan segera dilaksanakan di sepanjang jalan yang termasuk pada wilayah Panongan, khususnya jalan yang dianggap rawan perbuatan tindak criminal/pembegalan. Melihat adanya permintaan warga yang sangat membutuhkan penerangan jalan ini, maka kami melaksanakan Tri Darma Perguruan Tinggi serta menjadi salah satu kewajiban dosen dalam melaksanakan pengabdian pada masyarakat .Dengan ini pelaksanaan pengabdian kepada masyarakat mengambil kasus dengan judul : Pemasangan Lampu Penerangan Jalan Di Kp. Benda RT.10 RW 04 Desa Mekar Jaya Kecamatan Panongan Kabupaten Tangerang

\section{Metode}

Tahapan-tahapan pelaksanaan kegiatan pengabdiaan ini sebagai berikut:

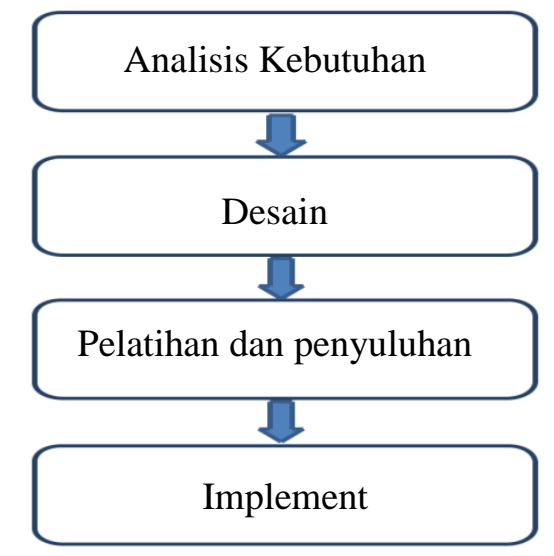

Gambar 1. Diagram alir Tahapan Kegiatan

Dari gambar.1. dapat dijelaskan Tahapan kegiatan sebagai berikut:

1. Analisis kebutuhan

a. Tahapan awal ini berupa analisis kebutuhan meliputi kebutuhan output, proses dan hasil analisis kebutuhan, dipresentasikan kepada kelompok masyarakat, untuk mendapatkan masukan yang sesuai dengan kebutuhan.

b. Tim membuat solusi alternatif yang sesuai dengan kebutuhan dan sumber daya yang tersedia, agar solusi yang ditawarkan dapat dijalankan oleh pihak masyarakat dan pemerintahan desa dan tim menyepakati solusi yang dipilih untuk diterapkan.

c. Analisis Manfaat Ekonomi dari Lampu Tenaga Surya yang dipasang dimana analisis dari segi ekonomi pada lampu tenaga surya yang terpasang dilakukan untuk melihat manfaat dari sisi ekonomi dibandingkan dengan penggunaan lampu pijar untuk PJU. Selama ini untuk beberapa ruas jalan kampung, warga berinisiatif memasang lampu PJU dengan menarik kabel dari rumah warga atau dari tiang lampu PLN. Lampu yang terpasang merupakan lampu pijar atau lampu TL karena menurut warga lampu pijar lebih murah daripada lampu LED. Pada poin ini, akan dianalisis perbandingan dari sisi ekonomi terhadap PJU lampu surya dengan PJU lampu pijar untuk 1 titik lampu selama kurun 3 tahun 
2. Pelatihan dan Penyuluhan

Selain melakukan pemasangan lampu, tim PKM juga melakukan penyuluhan kepada warga tentang lampu tenaga surya khususnya tentang cara kerja lampu dan penyeleseian ditemui masalah pada lampu tersebut.

Warga sangat antusias dengan lampu surya yang dipasang, selain karena warga merasakan manfaat penerangannya, mereka juga tertarik dengan lampu surya tersebut karena ukurannya kecil dan pemasangannya relatif mudah dibanding lampu surya yang pernah mereka lihat.

Kegiatan pelatihan dan penyuluhan dilaksanaakan untuk memberikan informasi kepada warga sekitar mengenai energi baru dan terbarukan berikut cara pemasangan lampu jalan menggunakan solar cell dan cara pemeliharaannya.

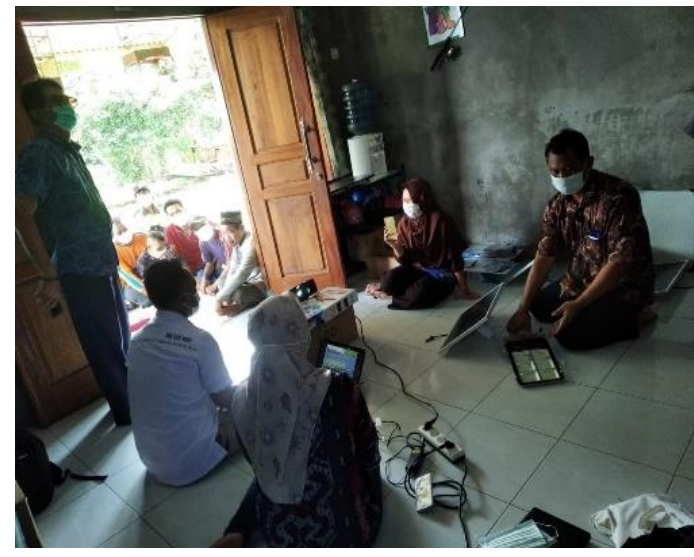

Gambar 2. Kegiatan Pelatihan Dan Penyuluhan

3. Dari hasil verifikasi dengan warga Kp.Blok Benda maka diputuskan Maksimalkan energy yang terbarukan dengan metode : Pemasangan Lampu Jalan berbasis pada tenaga Surya yang tindak lanjutnya dengan mengumpulkan warga untuk mengadakan pelatihan perakitan lampu bersumber pada tenaga surya dan penyuluhan tentang perawatan dan perbaikan kerusakan.

4. Implementasi

Produk yang telah dibuat diimplementasikan di Jalan Kp. Blok Benda dengan terlebih dahulu memberikan pelatihan / Penyuluhan tentang penggunaan dan perawatan lampu jalan tenaga surya kepada masyarakat sekitar

a. Perhitungan dan pengadaan lampu penerangan jalan

Perhitungan kebutuhan lampu :

Tinggi tiang 5 meter menurut SNI_7391_2008

Kebutuhan intensitas penerangan jalan lokal menurut SNI_7391_2008 5 lux

Lebar jalan 5 meter, Panjang jalan 80 meter

Jumlah tiang dan titik lampu jalan :

Menurut tabel pada SNI_7391_2008 Bahwa lebar jalan 5 meter dan tinggi tiang 5 meter membutuhkan jarak antar tiang 32 meter dan dipilih jarak antar tiang 20 meter,maka tiang yang ddibutuhkan 5 tiang lampu

Kapasitas daya lampu jalan

$\frac{\text { Luas area } \times \text { Besar Intensitas peneranagn }}{\text { jumlah titik lampu }}=\frac{400 \times 5 \text { lux }}{5}=400$ lumen 
Dengan mengasumsikan faktor kehilangan cahaya 0,67, maka dibutuhkan 668 lumen tiap lampu. Jika menggunakan lampu led maka dibutukan lampu led dengan kapasitas 90 watt dibulatkan 100 watt (1 watt menghasilkan 10 Lumen).

Di pasaran lampu jalan led 100 watt dijual dalam satu paket dengan speksifikasi baterai 3,2 volt $30000 \mathrm{mAh}$, solar cell $6 \mathrm{v} / 30$ watt, durasi nyala 12 jam dan waktu pengisian 5 jam

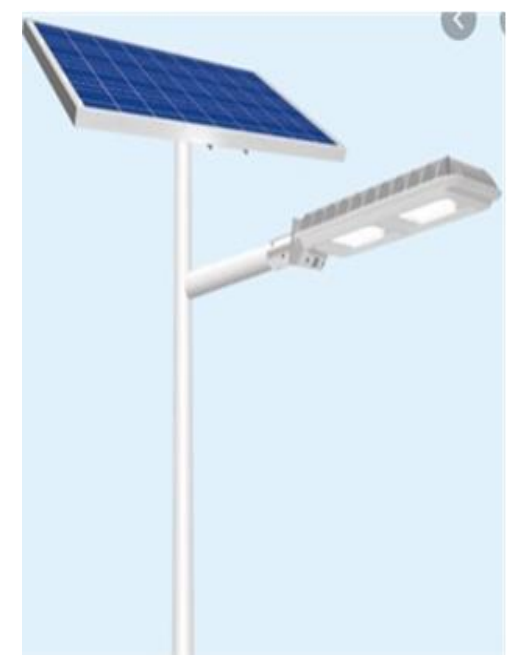

Gambar 3. Unit Lampu Jalan Tenaga Matahari

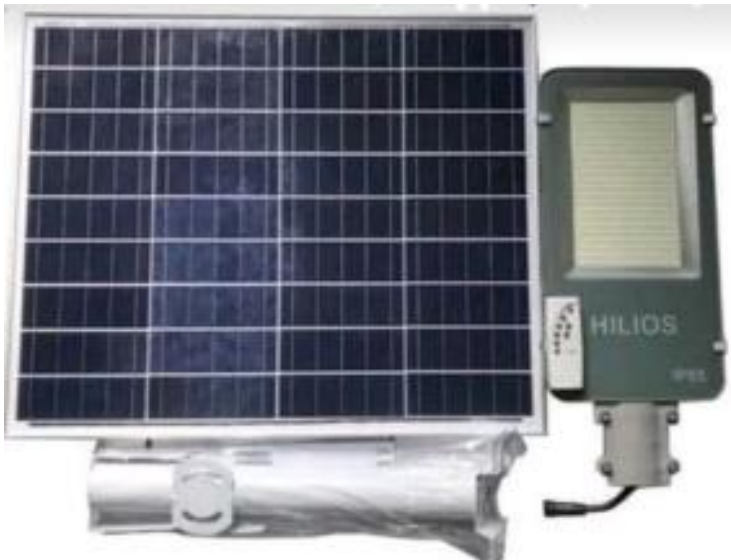

Gambar 4. Paket Solar Cell Beserta Lampu Dan Baterai

b. Pembuatan tiang dan perakitan lampu penerangan jalan

Pembuatan lampu jalan menggunakan pipa besi hitam diameter 2,5" dan 1,5", panjang tiang 5,5 meter serta dibentuk sesuai gembar 4. Dengan kedalaman penanamam tiang ke tanah 0,5 meter

c. Pemasangan unit lampu penerangan jalan

Pemasangan unit lampu jalan dirakit pada tiang dengan solar cell menghadap arah dominan datangnya sinar matahari.Kemudian tiang lampu ditanam sedalam $50 \mathrm{~cm}$ dengan lubang tanam diameter 1 meter dicor dengan campuran pasir semen dan kerikil split. 

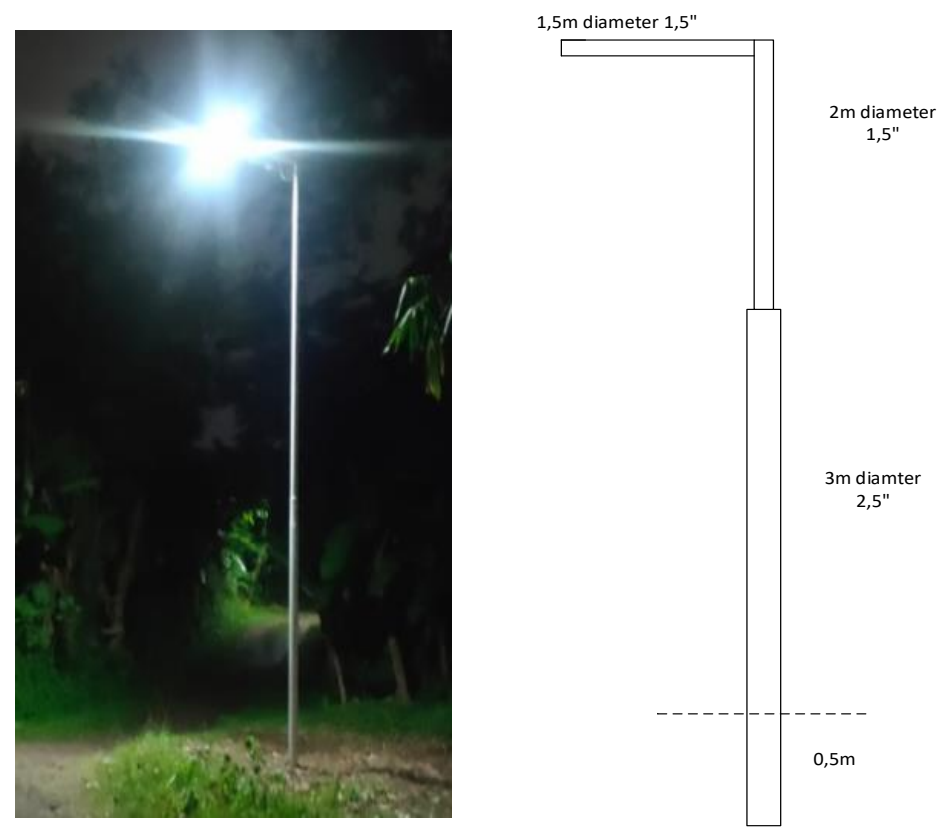

Gambar 5. Tiang Lampu Jalan Terpasang Beserta Ukuran
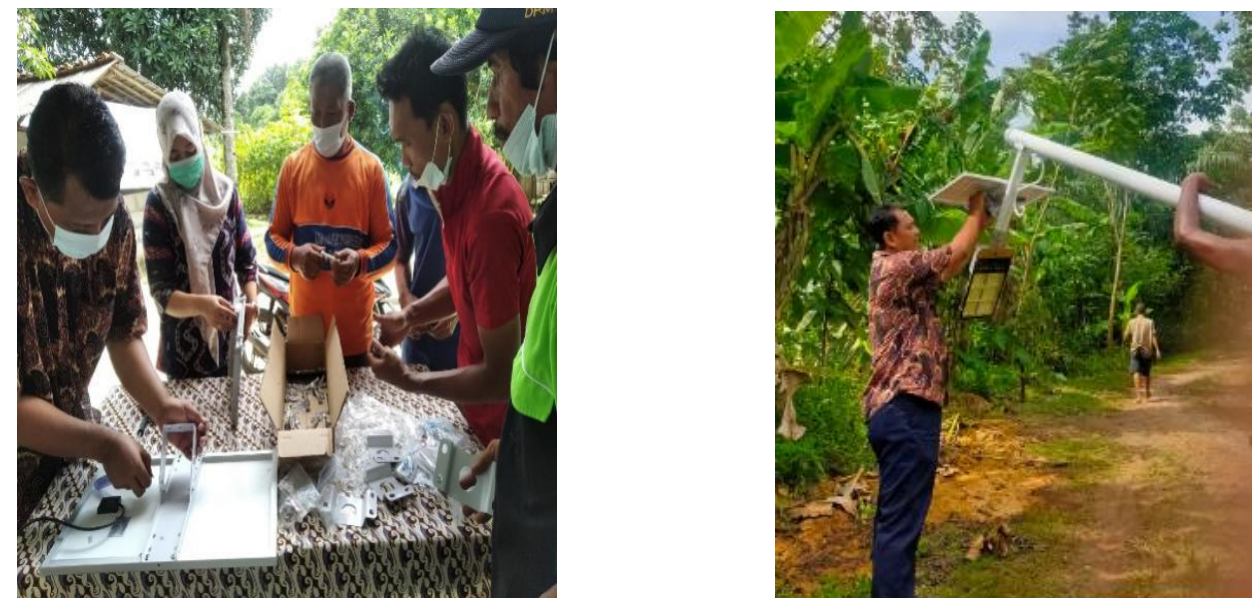

Gambar 6. Pelaksanaan Pemasangan Lampu Jalan

\section{Jadwal Pelaksanaan Kegiatan}

Tanggal 4 Desember 2020

Pukul 07.00 WIB, persiapan kegiatan PKM,

Pengadaan material seperti : Tiang lampu, lampu Solar sel, batu pasir, pasir pasang, split, semen dan peralatan dukung.

1. Pukul 09.00 WIB, pembukaan PKM mengenai pemasangan lampu jalan oleh KABAAK Bpk. Sukarwoto dan kepala desa Mekar Jaya Bpk Qomarudin

2. Pelaksanaan dimulai dengan penggalian lubang pondasi buat tiang lampu jalan

3. Setelah itu dipasang tiang lampu dan diberi campuran adukan semen ,pasir, batu (cor beton)

4. Pemasangan lampu jalan pada area yang terkena sinar matahari untuk solar sel

Tanggal 5 Desember 2020

1. Pukul 08.00 WIB melanjutkan pekerjaan pemasangan tiang lampu jalan

2. Pukul 09.00 WIB diadakan pelatihan dan pemberian wawasan tentang listrik tenaga surya 
Setelah selesai pemasangan tiang lampu dilakukan finishing atau perapian pada cor beton podasi lampu jalan.

\section{Hasil dan Pembahasan}

\section{A. Hasil}

Harapan dengan pelaksanaan Pengabdian Kepada Masyarakat (PPM) tentang Pemasangan Lampu Penerangan Jalan Menggunakan Tenaga Surya (Solar Cell) Di Kp. Benda Rt.10 Rw 04 Desa Mekar Jaya Kecamatan Panongan Kabupaten Tangerang adalah sebagai berikut:

1. Kondisi Awal

Dengan belum terpasangnya lampu jalan dapat mengurangi rasa nyaman pada factor keamanan yaitu warga yang beraktivitas khususnya pada malam hari dengan resiko yang tinggi dengan mudah akan terjadinya factor pembegalan atau tindak kriminal.

2. Kondisi Akhir

Rencana strategis jangka pendek yaitu pengadaan lampu jalan akan direalisasikan guna meningkatkan keamanan dan kenyamanan warga sehingga aktifitas warga sekitar lebih aman . Selain itu, pelaksanaan pemasangan penerangan jalan tersebut dapat memberikan pengetahuan bagi warga tentang cara pemasangan lampu jalan.Pemasangan jalan tersebut sesuai standar yang ada sehingga besaran intensitas penerangan pada area tersebut dapat tercukupi

\section{B. Pembahasan}

Lampu dilengkapi sensor cahaya yang dapat mendeteksi ada tidaknya cahaya. Sensor tersebut yang akan memicu penyalaan lampu otomatis jika cahaya di sekelilingnya gelap/ redup. Sebaliknya, lampu akan padam otomatis jika terdapat cahaya atau waktu siang hari. Artinya lampu surya ini dapat menyala otomatis ketika matahari sudah terbenam dan dapat mati otomatis saat matahari terbit, selama berfungsi normal.

Pengujian di lapangan dilakukan pada tanggal 5 Februari 2021 pukul 19.10 menit sampai pukul 19.45.menggunakan metode jala jala dan alat ukur lux meter tipe HIOKI 4321 dengan hasil sebagai berikut

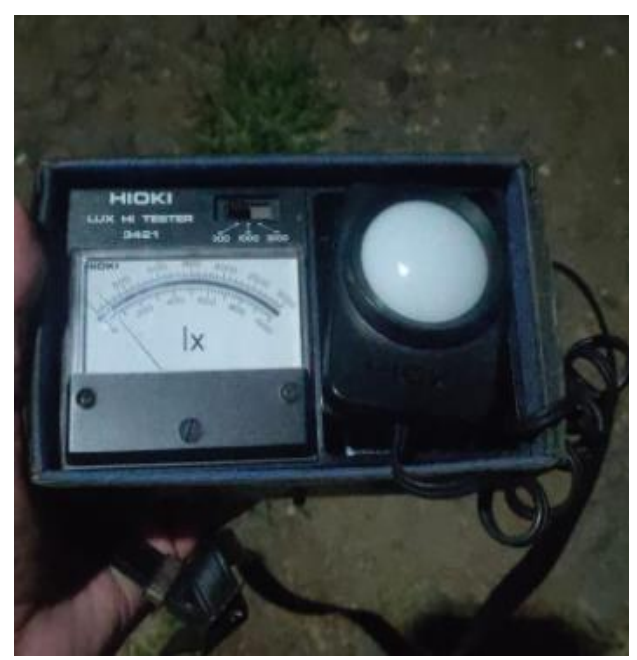

Gambar 7. Lux Meter HIOKI 4321 
Tabel 1. Hasil Pengukuran

\begin{tabular}{|c|c|c|c|c|c|c|c|}
\hline $\begin{array}{c}\text { Titik } \\
\text { Ukur }\end{array}$ & Hasil Ukur & $\begin{array}{c}\text { Titik } \\
\text { Ukur }\end{array}$ & Hasil Ukur & $\begin{array}{c}\text { Titik } \\
\text { Ukur }\end{array}$ & $\begin{array}{c}\text { Hasil } \\
\text { Ukur }\end{array}$ & $\begin{array}{c}\text { Titik } \\
\text { Ukur }\end{array}$ & Hasil Ukur \\
\hline $\mathbf{A 1}$ & 0 & B1 & 0 & C1 & 0 & D1 & 0 \\
\hline $\mathbf{A 2}$ & 0 & B2 & 0 & C2 & 2 & D2 & 3 \\
\hline $\mathbf{A 3}$ & 0 & B3 & 2 & C3 & 3 & D3 & 3 \\
\hline A4 & 3 & B4 & 3 & C4 & 5 & D4 & 5 \\
\hline A5 & 7 & B5 & 10 & C5 & 10 & D5 & 10 \\
\hline A6 & 10 & B6 & 15 & C6 & 25 & D6 & 28 \\
\hline A7 & 10 & B7 & 12 & C7 & 15 & D7 & 20 \\
\hline A8 & 5 & B8 & 8 & C8 & 10 & D8 & 10 \\
\hline A9 & 3 & B9 & 3 & C9 & 5 & D9 & 5 \\
\hline A10 & 0 & B10 & 0 & C10 & 5 & D10 & 3 \\
\hline A11 & 0 & B11 & 0 & C11 & 0 & D11 & 0 \\
\hline
\end{tabular}

Berdasarkan tabel tersebut maka didapatkan nilai intensitas penerangan rata rata adalah 5,86 $\operatorname{lux}$

\section{Kesimpulan}

\section{Kesimpulan}

Kegiatan Pengabdian Kepada Masyarakat melaksanakan pemasangan lampu penerangan jalan dengan menggunakan tenaga surya ini akan bermanfaat bagi warga sekitar dan terciptanya keadaan kamtibmas yang terkendali serta membuat mobilitas warga lebih baik. Penyuluhan diberikan kepada warga agar dapat memberi wawasan tentang listrik tenaga surya yang ramah lingkungan dan juga daspat memberikan bahwa sumber daya alam yang terbarukan belum maksimal digunakan untuk kehidupan manusia. Selain itu juga diberikan pelatihan untuk perawatan listrik tenaga surya.

\section{Saran}

Perlunya diberikan pengetahuan dan pengembangan kepada masyarakat agar dapat memanfaatkan sumber daya alam untuk menghasilkan sumber daya listrik, banyak tempat tempat di pedesaan yang masih memerlukan pencahayaan di sarana umum

\section{Ucapan Terima Kasih}

Dengan terlaksananya kegiatan Pengabdian Kepada Masyarakat sebagai salah satu unsur kewajiban Dosen tentang Tri Darma Perguruan Tinggi. Penulis mengucapkan terima kasih kepada Direktur Politeknik Penerbangan Indonesia Curug yang telah memberikan kesempatan melaksanakan PKM. Unit terkait yang memberikan dukungan baik dalam pemikiran dan tenaga. Seluruh warga desa di Kp. Blok Benda RT.10 RW. 04 Desa Mekar Jaya Kec. Panongan Tangerang Banten atas bantuanya. Dan semua pihak yang tidak dapat saya sebutkan satu persatu, semoga amal ibadahnya diberikan imbalan dari Allah SWT. 


\section{Daftar Pustaka}

H. Ponto. (2016), Dasar Teknik Listrik, Yogyakarta: CV Budi Utama.

M.S. Yohandri, M.Si. Ph.D dan Drs. Asrizal. (2016), Elektronika Dasar 1: Komponen, Rangkaian, Dan Aplikasi Edisi Pertama.

Tri Wahyu Oktaviana Putri, Adri Sene, Yoakim Simamora, Dwi Anggaini, Pemanfaatan Energi Surya untuk Penerangan Jalan \& Fasilitas Umum di Desa Sukarame Kab. Lebak Banten, Jurnal Pengabdian Pada Masyarakat Menerangi Negeri ISSN: 2655 Vol. 1, No. 2, Juli 2019

Standar Nasional Indonesia (SNI 7391:2008) Spesifikasi Penerangan Jalan Di Kawasan Perkotaan

Kementerian ESDM. 2018. Executive Summary RUPTL PT.PLN (Persero) 2018-2027 pada acara Diseminasi RUPTL 2018-2027.

https://www.esdm.go.id/assets/media/content/contentringkasan-ruptl-2018-2027.pdf, 